\title{
Analysis of Ancient DNA from Coprolites: a Perspective with Random Amplified Polymorphic DNA-Polymerase Chain Reaction Approach
}

\author{
Alena M Iñiguez/ ${ }^{+}$, Adauto Araújo*, Luiz Fernando Ferreira*, Ana Carolina P Vicente
}

Laboratório de Genética Molecular de Microorganismos, Departamento de Genética, Instituto Oswaldo Cruz-Fiocruz, Av. Brasil 4365, 21045-900 Rio de Janeiro, RJ, Brasil *Escola Nacional de Saúde Pública-Fiocruz, Rio de Janeiro, RJ, Brasil

The aim of this work was to determine approaches that would improve the quality of ancient DNA (aDNA) present in coprolites to enhance the possibility of success in retrieving specific sequence targets. We worked with coprolites from South American archaeological sites in Brazil and Chile dating up to 7,000 years ago. Using established protocols for aDNA extraction we obtained samples showing high degradation as usually happens with this kind of material. The reconstructive polymerization pretreatment was essential to overcome the DNA degradation and the serial dilutions helped with to prevent polymerase chain reaction (PCR) inhibitors. Moreover, the random amplified polymorphic DNA-PCR has been shown to be a reliable technique for further experiments to recover specific aDNA sequences.

Key words: molecular paleoparasitology - coprolites - random amplified polymorphic DNA - ancient DNA polymerase chain reaction

The analysis of ancient DNA (aDNA) from archaeological specimens has revolutionized different research fields especially the study of human evolution and the origin of human infectious diseases. Gene fragments from eukaryotic and prokaryotic organisms have been successfully detected from human bones and tissues (Fricker et al. 1997, Ubaldi et al. 1998, Gulh et al. 1999, Cano et al. 2000, Ferreira et al. 2000, Zink et al. 2001). All of these studies focused on the recovery of aDNA from a specific organism or a determined gene sequence. However, recovering aDNA is still a challenge due to aDNA damage and contamination with modern DNA (Hofreiter et al. 2001, Marota et al. 2002). In this paper we deal with aDNA damage in order to improve the quality and success of methods.

aDNA retrieved from ancient samples is often degraded into short pieces by hydrolytic or oxidative damage, reducing the possibility of DNA amplification or at least to obtain large polymerase chain reaction (PCR) fragments (Lindalh 1993, Marota et al. 2002). Golenberg et al. (1996) demonstrated that it is possible to reconstruct degraded DNA by polymerization on self-primed DNA fragments. The initial highly fragmented templates can be partially re-assembled by the reconstructive polymerization (RP) making it possible to recover some sequences by PCR. On the other hand, random amplified polymorphic DNA (RAPD) is a PCR technique variation in which only a short and arbitrary nucleotide sequence is used as a primer allowing the amplification of DNA sequences without pre-

This work was founded by $\mathrm{CNPq}$ and IOC-Fiocruz.

${ }^{+}$Corresponding author. Fax: +55-21-2260.4282. E-mail: alena@ioc.fiocruz.br

Received 26 August 2002

Accepted 25 November 2002 vious nucleotide information (Wels et al. 1990, CaetanoAnollés et al. 1991). This work aims to estabilish a feasible protocol to retrieve aDNA from coprolites in order to perform further paleoparasitological studies.

\section{MATERIALS AND METHODS}

We used 29 human coprolites from the Laboratory of Paleoparasitology Collection (ENSP-Fiocruz), previously examined for the presence of parasites (Table) as a DNA source. Fourteen samples were negative in initial paleoparasitological analyses and the presence of eggs and larvae of possible human parasites was recorded in the remaining 16 samples (Table) (Ferreira et al. 1984, Iñiguez 1998).

Preparation and extraction of DNA was conducted in a laboratory free of other previous DNA manipulations. Non-disposable materials and benches were treated with 95\% sodium hipochlorite as well as irradiated with UV light for several hours. All reagents were maintained in volumes suitable for a single use. PCR reaction mixture was exposed to UV light previously to the addition of enzyme and aDNA. Extraction environmental and PCR negative controls were always included (Loreille et al 2001). Samples were exposed to UV light for 30 min on all faces. After those surfaces were removed, the core was ground, and 5-2 $\mathrm{g}$ were hydrated on $\mathrm{ddH}_{2} \mathrm{O}$ or TE buffer (Tris-HCl $10 \mathrm{mM}$, EDTA 1mM, pH 8.0). Samples were treated with $400 \mu \mathrm{l}$ digestion buffer $(\mathrm{NaCl} 100 \mathrm{mM}$, Tris- $\mathrm{HCl} 50 \mathrm{mM}$, SDS $1 \%$, EDTA $50 \mathrm{mM}, \mathrm{pH} 8.0$ ), and $60 \mu \mathrm{l}$ proteinase $\mathrm{K} 10$ $\mathrm{mg} / \mathrm{ml}$ (Gibco-BRL) incubated at $55-60^{\circ} \mathrm{C}$ for $48 \mathrm{~h}$. The DNA was extracted using the phenol/chloroform method and purified in a silica resin column (Glass Max DNA Isolation Spring Cartridge System Gibco-BRL). DNA was quantified in the spectrophotometer and analyzed on silver stained 5\% PAGE gel. DNA from the samples $(1 \mu \mathrm{g})$ was spotted onto a nylon membrane. A ribosomal operon fragment was used as a radiolabeled probe. The hybrid- 
TABLE

Coprolite paleoparasitological analysis

\begin{tabular}{|c|c|c|}
\hline Excavation site $^{a}$ & Parasite & Sample number \\
\hline Gruta do Gentio II $^{b}$ & $\begin{array}{l}\text { Hookworm } \\
\text { Hookworm, } T \text {. trichiura, unidentified larvae } \\
\text { Unidentified larvae } \\
\text { T. trichiura, unidentified larvae }\end{array}$ & $\begin{array}{l}4,16 \\
22 \\
38,44,92 \\
24,43,107\end{array}$ \\
\hline Cultura Azapa $^{c}$ & Helmints & 154 \\
\hline Antofagasta $^{c}$ & $\begin{array}{l}\text { T. trichiura, Strongyloidea } \\
\text { T. trichiura } \\
\text { Diphyllobothrium pacificum }\end{array}$ & $\begin{array}{l}166 \\
173 \\
175,176,177\end{array}$ \\
\hline Caserones $^{c}$ & Enterobius vermicularis & 385 \\
\hline
\end{tabular}

$a$ : coprolite samples collected in Boqueirão da Pedra Furada, Piauí, Brazil, dated of $7230 \pm 80$ years BP $(\mathrm{n}=2)$ are not shown; $b$ : Unai, Minas Gerais, Brazil, coprolites dated of $3490 \pm 120$ years BP $(n=17) ; c$ : coprolites from Azapa 800 BC $(n=5)$; Antofagasta $(n$ $=5)$, and Caserones $(n=1)$, Tarapaca Valley dated of 400 BC to $800 \mathrm{AD}$, Chile.

ization and washing were carried out in low stringency conditions (Sambrook et al. 1989). Enzymatic amplification was conducted in a total volume of $50 \mu \mathrm{l}$, as follows: 10X PCR Buffer [200 mM Tris- $\mathrm{HCl}$ (pH 8.0), $500 \mathrm{mM} \mathrm{KCl}$ ], 1.5-6 mM MgCl2, $0.5 \mu \mathrm{M}$ of each dATP, dCTP, dGTP, dTTP, $125 \mathrm{ng} / \mu \mathrm{l}$ of oligonucleotides and $5 \mathrm{U}$ of Taq polymerase. Different DNA concentrations were tested: 100-200 ng, $10 \mathrm{ng}, 1 \mathrm{ng}$ and $100 \mathrm{pg}$ for each sample. The random oligonucleotides and Thermal Cycler program used as describe by Coelho et al. (1995). RP method was performed before PCR amplification, as previously described by Golenberg et al. (1996).

\section{RESULTS}

aDNA was retrieved from 29 coprolite samples from different archaeological sites in Brazil and Chile. DNA concentration was determined by its absorbance at 260 , 280 and $320 \mathrm{~nm}$ and the results indicate that extracts have high concentrations of free nucleotides (Iñiguez 1998). Acrylamide gel electrophoresis showed aDNA with an intense degradation (data not shown). Hybridization revealed a strong signal in some samples (Fig. 1). RAPDPCR using DNA concentration around 100-200 ng produced no detectable amplification. In order to verify a possible PCR inhibition, aDNA samples were diluted se-

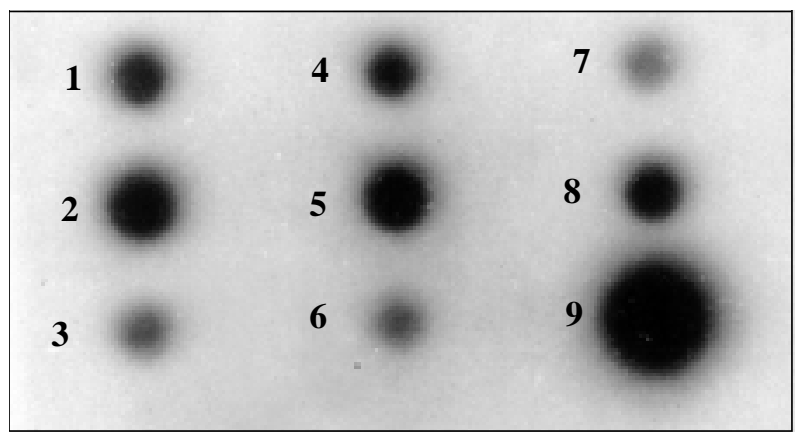

Fig. 1: ancient DNA hybridization with ribosomal probe. Dots - 1 to 8: coprolite samples $4,43,118,22,153,385,24,166$, respectively; 9: positive control rially and then amplification was possible in sample 4 and 43 using primers 131 and 139. Additionally, the RP pretreatment permitted amplifications in samples 22, 153 and 166 as well as 4 and 43 using primers 131, 61 and 62 (Fig. 2).

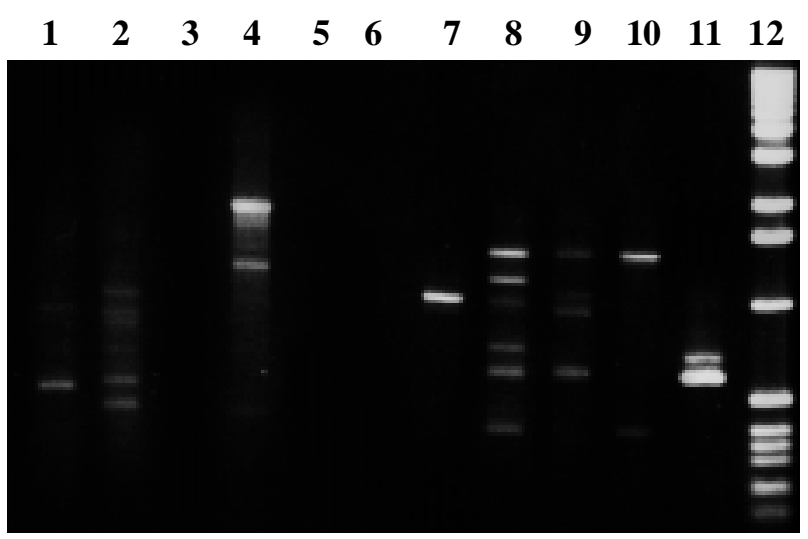

Fig. 2: random amplified polymorphic DNA-polymerase chain reaction results from human coprolites. Lanes - 1-4: Primer 139; 511: Primer 131; 1, 7: 43III; 2, 8: 4I; 3, 9: 4II; 4: positive control 139; 5: 43I; 6: 43II; 10: 4III; 11: positive control 131; 12: $1 \mathrm{~kb}$ DNA ladder (Gibco BRL). I: $10 \mathrm{ng}$; II:1 ng; III: 100 pg aDNA concentration (1.5\% agarose gel electrophoresis)

\section{DISCUSSION}

The application of molecular techniques for the analysis of fecal material has allowed recovery of information about individuals, populations, food habits, gender, and pathogens (Kohn \& Wayne 1997). Only recently, DNA from coprolites was analyzed in order to determine plant and animal components of diet (Poinar et al. 1998, 2001), bacterial flora, and parasitic infection (Cano et al. 2000, Loreille et al. 2001). Usually these techniques target ribosomal, chloroplast, or mitochondrial genes and then the real nature of the amplicons are determined by nucleotide sequencing analysis. Before starting the search for spe- 
cific organisms or DNA sequences in archaeological material, it is important to be sure about the DNA quality, in terms of feasibility of PCR application. With the combination of techniques presented here, we were able to show that it is possible to improve the DNA quality using RP. RP repairs partially degraded DNA, assembling larger enough sequences to generate amplicons using RAPDPCR procedure. Most of the samples showed degradation at $320 \mathrm{~nm}$ absorbance, indicated by the high concentration of free nucleotides and silver staining acrylamide gel runs. On the other hand, the dot blot procedure showed evidence of sequences with quality and length enough to hybridize with a ribosomal probe. As the presence of contaminating compounds that usually limit the PCR performance do not interfere with this procedure, the result was a strong signal in most of the samples. PCR inhibition was detected in sample 43 and overcame only after sample dilutions.

As shown here, the difficulty in recovering aDNA is mainly a challenge due to DNA damage. RP and RAPD approaches can be useful, even when specific aDNA target is the objective of the work. Ancient DNA was recovered in order to establish a coprolite molecular pattern. Perspectives for the study of parasite aDNA in coprolites are promising; as it offers new knowledge on the infectious diseases and the history of host-parasite relationships.

\section{REFERENCES}

Araujo A, Reinhard K, Bastos O, Costa LC, Iñiguez AM, Pirmez C, Vicente ACP, Morel CM, Ferreira LF 1998. Paleoparasitology: perspectives with new techniques. Rev Inst Med Trop São Paulo 40: 371-376.

Caetano-Anollés G, Bassam BJ, Gresshoff PM 1991. DNA amplification using very short arbitrary oligonucleotide primers. Biotechnology 9: 556-557.

Cano RJ, Tiefenbrunner F, Ubaldi M, Del Cueto C, Luciani S, Cox T, Orkand P, Kunzel KH, Rollo F 2000. Sequence analysis of bacterial DNA in the colon and stomach of the Tyrolean Iceman. Am J Phys Anthropol 112: 297-309.

Coelho A, Vicente ACP, Baptista MAS, Momen H, Santos FARW, Salles CA 1995. The distinction of pathogenic Vibrio cholerae groups using arbitrarily primed PCR fingerprints. Res Microbiol 146: 671-683.

Ferreira LF, Britto C, Cardoso MA, Fernandes O, Reinhard K, Araujo A 2000. Paleoparasitology of Chagas disease revaled by infected tissues from Chilean mummies Acta Trop 75: 79-84.
Ferreira LF, Ribeiro Filho BM, Araújo A, Confalonieri NEC, Nuñez, L 1984. Enterobius vermicularis eggs in precolombian human coprolites from Chile. Paleopathol Newsl 46: 4-5.

Fricker EJ, Spigelman, M, Fricker CR 1997. The detection of Escherichia coli DNA in the ancient remains of Lindow Man using the polymerase chain reaction. Lett Appl Microbiol 24: 351-354.

Golemberg EM, Bickel A, Weihs P 1996. Effect of highly fragmented DNA on PCR. Nucleic Acids Res 24: 5026-5033.

Guhl F, Jaramillo C, Vallejo GA, Yockteng R, Cardenas-Arroyo F, Fornaciari G, Arriaza B, Aufderheide AC 1999. Isolation of Trypanosoma cruzi DNA in 4,000-year-old mummified human tissue from Northern Chile. Am J Phys Anthropol 108: 401-407.

Hofreiter M, Serre D, Poinar HN, Kuch M, Pääbo S. 2001. Ancient DNA. Nature Reviews Genetics 2: 353-359.

Iñiguez AM 1998. Análise de DNA Ancestral para o Estudo de Infecções Parasitárias em Populações Pré-históricas, MSc Thesis, Fundação Oswaldo Cruz, Rio de Janeiro, 87 pp.

Kohn MK, Wayne RK 1997. Facts from feces revisited. Trends Ecol Evo 12: 223-227.

Lindahl T 1993. Instability and decay of the primary structure of DNA. Nature 362: 709-715.

Loreille O, Roumat E, Verneau O, Bouchet F, Hanni C 2001. Ancient DNA from Ascaris: extraction amplification and sequences from eggs collected in coprolites. Int J Parasitol 31: 1101-1106.

Marota I, Basile C, Ubaldi M, Rollo F 2002. DNA decay rate in papyri and human remains from Egyptian archaeological sites. Am J Phys Anthropol 117: 310-318.

Poinar HN, Hofreiter MW, Spaulding G, Martin PS, Stankiewicz A, Bland H, Evershed RP, Possnert G, Pääbo S 1998. Molecular coproscopy: dung and diet of extinct ground sloth Nothrotheriops shastensis. Science 281: 402-406.

Poinar HN, Kuch M Sobolik K, Barnes I, Stankiewicz AB, Kuder T, Spaulding WG, Bryant VM, Cooper A, Pääbo S 2001. A molecular analysis of dietary for three archaic Native Americans. PNAS 98: 4317-4322.

Sambrook J, Fritsch E, Maniatis T. 1989. Molecular Cloning: A Laboratory Manual, 2nd ed., Plainview: Cold Spring Harbor Laboratory Press, Cold Spring Harbor.

Ubaldi M, Luciani S, Marota I, Fornaciari G, Cano RJ, Rollo F 1998. Sequence analysis of bacterial DNA in the colon of an Andean mummy. Am J Phys Anthropol 107: 285-295.

Wels J, McClelland M 1990. Fingerprinting genomes using PCR with arbitrary primers. Nucleic Acids Res 18: 72137218.

Zink A, Haas CJ, Reischl U, Szeimies U, Nerlich AG 2001. Molecular analysis of skeletal tuberculosis in an ancient Egyptian population. J Med Microbiol 50: 355-366. 